\title{
Podkastlar Dinleme ve Sesletim Dersinde Anlamlı Girdi Sağlayabilir mi?*
}

\section{Can Podcasts Provide Meaningful Input in a Listening and Pronunciation Class?}

\begin{abstract}
Arif BAKLA**
Received: 23 January 2018

Research Article

Accepted: 02 April 2018

ABSTRACT: The goal of this case study was to explore intermediate EFL learners' experiences of using short podcasts to improve their listening, speaking and pronunciation. The participants $(\mathrm{N}=8)$ listened to podcasts about diverse topics of their interest throughout an academic year. Each week they were instructed to present what they listened to in a round-table discussion or in presentations. The instructor took part in the discussions as well, providing feedback at the end of each session. For this study, a focus group interview was carried out with the participants. The focus group interview was transcribed and coded in NVivo v10, using a three-phase approach to coding. The analysis of the focus group interview revealed that the students were basically fond of listening to podcasts, but not talking about them; they also thought listening to podcasts provided them with meaningful input and somehow helped improve their listening and speaking skills. In this study, the researcher explored what it means for them to be a part of a lesson that is basically different from mainstream classes and discussed the implications of getting students to move out of their comfort zones by changing study habits.
\end{abstract}

Keywords: podcasts, listening, speaking, pronunciation, meaningful input.

ÖZ: Bu durum çalışmasının amacı İngilizceyi yabancı dil olarak öğrenen öğrencilerin dinleme, konuşma ve sesletimlerini geliştirmek için podkast kullanımına dair deneyimlerini araştırmayı amaçlamaktadır. Katılımcılar ( $\mathrm{S}=8)$ bir akademik yıl boyunca ilgi duydukları geniş bir yelpazede podkast dinlemişlerdir. Öğrencilerden her hafta dinlediklerini bir yuvarlak masa tartışmasında tartışmaları veya sunum yapmalarını istenmiştir. Öğretmen de tartışmalara katılmış ve ders sonunda geri bildirimde bulunmuştur. Veri toplamak amacıyla, katılımcılar ile bir odak grup görüşmesi yapılmış ve görüşme dökümleri Nvivo v10 yazılımı ile üç aşamalı bir kodlama yöntemi ile kodlanmış ve analiz edilmiştir. Odak grup görüşmelerinin analizinden elde edilen sonuçlar öğrencilerin podkast dinlemekten hoşlandıklarını; ancak dinledikleri hakkında konuşmayı sevmediklerini ortaya çıkarmıştır. Katılımcılar aynı zamanda podkast dinlemenin dinleme ve konuşma becerilerini geliştirmeye yardımcı olduğunu ifade etmişlerdir. Bu çalışmada araştırmacı; katılımcıların alışılagelmiş derslerden farklı bir dersin parçası olmalarının onlar için ne anlama geldiğini araştırmakta ve öğrencilerin çalışma alışkanlıklarını değiştirerek onları rahatlık bölgelerinden çıkarmaya çalışmanın anlamını tartışmaktadır.

Anahtar kelimeler: podkastlar, dinleme, konuşma, sesletim, anlamlı girdi

\footnotetext{
* An earlier version of this paper was delivered as an oral presentation at SCOFOLA17 (Twenty-first Century Skills in Language Research) at Bülent Ecevit University, on September 8-10, 2017.

${ }^{* *}$ Dr., Cumhuriyet University, Sivas, Turkey, arifbakla@ gmail.com
}

Citation Information

Bakla, A. (2018). Can podcasts provide meaningful input in a listening and pronunciation class? Kuramsal Eğitimbilim Dergisi [Journal of Theoretical Educational Science], 11(4), 772-788. 


\section{Introduction}

As a receptive skill, listening is a fundamental source of input in language acquisition. However, it usually proves challenging to help students improve their listening skills in a limited class time that is often reserved for reading, speaking, grammar and vocabulary (Facer, Abdous, \& Camarena, 2008). Podcasts that seem to serve this function have been immensely popular for the last decade (Ahn, Inboriboon, $\&$ Bond, 2016), probably because they could be downloaded to any digital device and could be used without limitations of time and space (Farangi, Nejadghanbar, Askary, \& Ghorbani, 2015; Naseri \& Motallebzadeh, 2016; Nesi, 2016; O’Bannon, Lubke, Beard, $\&$ Britt, 2011). Access could sometimes be a significant issue in technologically oriented projects, yet this hardly goes for podcasting as almost all young people own a kind of digital device, such as mobile phones, tablet computers or MP3 players. Podcasting turns digital devices into instructional tools that could be used to promote content and to improve language skills and areas (Abdous, Camarena, \& Facer, 2009). This is perhaps the reason why educational podcasting is getting more and more popular nowadays (Walls et al., 2010).

Some researchers have stressed the paucity of research on the pedagogical benefits of podcasts in language instruction (Chan, Chi, Chin, \& Lin, 2011; Farangi et al., 2015; Rahimi, \& Katal, 2012). Studies on podcasts have usually focused on learners' perceptions of usefulness or effectiveness of podcasts in learning, yet these studies have failed to clarify the extent to which they could provide meaningful input for foreign language learners. The input provided in the form of listening or reading materials is meaningful when students enjoy these materials and feel that they learn something new. However, whether the input that students are provided is meaningful is closely related with the feelings and thoughts of these students. This study aims to investigate the potential role of podcasts in providing learners with meaningful input. Therefore, in line with Rahimi and Katal's (2012) call for further qualitative research into possible problems in podcast use, this study aims to investigate the extent to which podcasts could provide meaningful input and explore how students select podcasts and study with them and what potential problems could prevent students from collectively reflecting on the contents of podcasts with their peers.

\section{Background to the Study}

Podcasts are usually series of audio/video files (the latter being referred to as "vodcasts," a blended word that is produced from the words "video" and "podcast") that are updated regularly by their creators and are downloaded automatically by subscribers with the help of an RSS feed. The term "podcast" itself was produced as a neologism of "iPod" and "broadcast" (Giordano, 2016). Bradbury (2016) defines it "as a piece of audio or video media that, when combined with an RSS feed, can be subscribed to by a worldwide audience" (p. 46). They usually come with a creative commons license, which resolves issues arising from content ownership.

According to a commonly cited taxonomy, podcasts can be substitutional, supplementary and creative (McGarr, 2009). Substitutional and supplementary podcasts are usually produced by teachers or professionals, whereas creative podcasts are produced by learners themselves. In recent years, there have been examples of student- 
generated podcasts (e.g., Giordano, 2016; Hazell-Yildirim \& Hoffman, 2010) as well. Such podcast projects help improve lower digital productivity levels in students which according to some research studies (e.g., Clark, Logan, Luckin, Mee, \& Oliver, 2009; Jones, Ramanau, Cross, \& Healing, 2010; Selwyn, 2009) pose a particular problem that should be addressed. Some other parameters used to classify podcasts include the nature of the content (informative content, feedback, authentic language and so forth), the medium in which the content is presented (audio or video), length, ownership and style (formal or informal) (Carvalho, Aguiar, \& Maciel, 2009).

There might be some cases in which a podcast is used to substitute a lecture, especially in distance learning classes, yet most podcasts are supplementary in nature; they function as additional materials that could support students outside the class. The former is not common in English language learning contexts because lecturing does not usually fit in the overall language pedagogy. This is because language learning classes are characterized by interaction and communication rather than one-way information transfer. In other words, podcasts as substitutes to traditional classes could be more applicable in content-based classes in which information transfer from the teacher to students is common.

\section{Uses of Podcasts}

Podcasts have been used for different purposes in language learning environments. They are so functional that Constantine (2007) describes them as a "goldmine of materials for teaching listening" (Online, para. 1). They are particularly suitable for extensive listening, in which language learners are exposed to authentic language for out-of-class practice. This could be just for pleasure or as a part of an assignment. Teacher created podcasts could function as a storytelling tool and some teachers utilize them to flip their classes (Bradbury, 2016). According to Heilesen (2010), students usually like recorded lectures as they use recordings to revise what they have learned or to catch up with the classes that they failed to attend. Podcasts could also be used to integrate language skills. In Alm's (2013) study, for example, students extensively listened to podcasts and shared their reflections in a blog with an authentic audience. Podcasts could also be used as tools for intensive in-class listening activities. For example, in a mixed-methods study, Şendağ, Gedik, Caner and Toker (2017) asked 29 Turkish-L1 learners of English in a listening and pronunciation class to listen to podcasts intensively for 10 weeks using tablet computers (the participants were involved in 29 hours of intensive listening in addition to regular instruction), while 29 other students received regular instruction. However, according to the results, this intensive listening did not lead to a statistically significant difference between the group's performance with respect to listening, speaking, critical thinking skills and listening strategies. Based on qualitative data collected to understand the results of the experiment, the authors concluded that some other factors such as motivation and attention could be at work as the participants reported that huge amounts of listening materials distracted them.

Podcasts come with other instructional uses in language learning classes. For example, students can publish for a real audience dispersed around the world in addition to their peers (Al Fadda, \& Al Qasim, 2013; Bradbury, 2016; Chan et al., 2011), and this usually motivates them (Bittenbender \& von Koss, 2008; Fox, 2008; Stanley, 2006; 
Sze, 2006). According to Stanley (2006), students care about what they produce if they intend to publish for a real audience (p. 6). As the speed of a podcast is adjustable, those who have difficulty in understanding faster speech could work with slower speeds or use transcripts. Although Fox (2008) considers the latter option as a controversial issue, there seems to be a consensus among researchers about its usefulness (Constantine, 2007; Hazell-Yildirim \& Hoffman, 2010; Hennig, 2017a, 2017b; Li, 2010; Lu, 2007; Yeh, 2013). Moreover, as claimed by Hennig (2017a), young learners prefer listening to authentic materials accompanied by a transcript. Similarly, a great majority of the participants in Fadda and AlQasim's (2013) study thought that transcripts could be useful. Moreover, transcripts could help learners deal with more difficult texts (Alm, 2013; Yeh, 2013). In Ashraf, Noroozi, and Salami's (2011) mixed-methods study with Iranian EFL students, podcasts were found to improve the participants' listening skills in addition to improving their self-regulation skills, vocabulary and grammar. The researchers also found that the participants had a positive attitude towards listening to podcasts. Moreover, language teachers could also ask their students to prepare transcripts of parts of podcasts. Still another use could be to introduce speech produced by non-native speakers of diverse backgrounds to help students practice understanding accented speech (Fox, 2008).

\section{Benefits of Podcasts}

Although academic effectiveness of podcasts is sometimes questioned due to inadequate longitudinal empirical studies, literature on podcasts (usually based on the findings from perception-based work) mention a number of benefits of using podcasts in language learning classes. In a number of research studies, podcasts were found to make a positive effect on students' attitudes (e.g., Abdous et al., 2009; Alshaikhi \& Madini, 2016; Lu, 2007), and they were thought to improve listening comprehension (Alm, 2013; Ashraf, Noroozi, and Salami, 2011 as cited in Al Fadda \& Al Qasim, 2013; Giordano, 2016; Li, 2010). In some other studies, podcasts were found to improve students' study practices (Facer et al., 2008). As they can be used anytime/anywhere and students have control over what to listen to, podcasts could be valuable materials for extensive listening and useful tools for personal and professional development. A particular benefit of podcasts is that they expose language learners to authentic language through the materials of their own choice (Al Fadda \& Al Qasim, 2013; Alm, 2013; Bittenbender \& Von Koss, 2008; Facer et al., 2008; Farangi et al., 2015; Hasan \& Hoon, 2013; Jain \& Hashmi, 2013). This is particularly important in input-poor contexts, in which students have limited opportunity to listen to language in authentic contexts. Students have access to podcasts on a great variety of topics; possibilities are actually endless. However, such great diversity of topics that could be selected can sometimes cause problems. For example, as Giordano (2016) warns, students might get confused by varying difficulty levels of the materials from different websites for an intended level.

Another significant benefit of listening to podcasts is that it helps individualize learning activities by allowing learners to select their own listening materials based on their learning styles and strategies (Farangi et al., 2015). Selecting content and portability both contribute to individualization because learners are able to listen to whatever they want and wherever they go. Moreover, another factor that promotes individualization is their full control over the audio (slowing down, rewinding and fast 
forwarding, repeating and so forth) (Fox, 2008; Giordano, 2016). Being able to replay the audio as desired is perhaps the most significant benefit of listening to podcasts (Heilesen, 2010). Podcasts could motivate students to do listening activities both inside and outside the class and arouse their interests in a variety of topics. They could also be used to develop other skills like reading or areas like grammar or vocabulary. As Nesi (2016) aptly puts it, podcasts help break the routine and motivate students to demonstrate their knowledge through a different method rather than traditional assignments. In addition, they can function as a tool for asynchronous communication among students themselves in a class or the global community of Internet users. As the present study investigates podcasts with respect to the concept of "meaningful input," this term deserves a special attention, so the next subsection discusses it.

\section{Meaningful Input}

Meaningful input assumes an important role in language acquisition and learning. Therefore, it occupies a key place in materials design and lesson planning. Probably because of this, Tomlinson (2011b) considered "meaningful and comprehensible input of language in use" as one of the key principles of materials design (as cited in McDonough, Shaw, \& Masuhara, 2013, p. 209). For successful language acquisition, learners should receive comprehensible input, which is defined as "the message acquirer is able to understand" (Krashen, 1985, p. 101). This input should be slightly ahead of a learner's current state of knowledge (i+1). Moreover, according to Krashen (1989), "comprehensible input, when delivered in sufficient quality and quantity, automatically contains all the appropriate structures for the acquirer" (p. 9). Such input is useful when the learner receives it in a low-stress environment. The combination of comprehensible input and low affective filter could help promote language acquisition (Krashen, 1982). If input is not comprehensible, students may find little value in listening to materials and eventually quit their attempts. Depending on what and how students are listening to, even authentic materials could be highly comprehensible. For example, in Mayora's (2017) study, although the participants listened to authentic materials, comprehensibility was not an issue probably because the students did narrow listening (i.e., they did a lot of listening on the same topic) or they listened to materials based on their own preferences. This indicates that authentic materials could be highly attractive for some students, like those in Alm's (2013) study, despite potential comprehension problems.

Another significant issue is the extent to which the input provided is meaningful. Input is meaningful as long as learners find value in reading or listening to the material. Unfortunately, most of the input that language teachers provide in the form of reading and listening texts in in-class situations are far from being meaningful because they are not based on individual needs and students feel forced rather than motivated while they read and listen to materials that are usually selected based on a "one-for-all" approach. Therefore, there is need for tools that could help learners listen to authentic materials and enjoy what they do.

One such tool could be extensive listening. Two fundamental principles of extensive listening are that there should be lots of materials to be listened to and learners should enjoy themselves by pursuing their interests or listening to materials related with their field of study. Podcasts could be very helpful in providing meaningful 
input in contexts where students do not have an opportunity to speak with foreigners. Providing learners with enough input is significant, particularly in contexts where students have limited opportunity to communicate in natural settings. Such input becomes meaningful when they are encouraged to find their own podcasts and listen to them just to enjoy themselves. Enjoyment in turn promotes meaningfulness. Meaningful input usually comes in the form of authentic language. Learners gain access to a variety of authentic materials if they use podcasts (Fox, 2008; Thorne \& Payne, 2005). Meaningful output is likely to emerge when students are engaged with authentic language and other online users (Giordano, 2016). In brief, podcasts could be useful tools for introducing meaningful input in extensive listening projects (Naseri, \& Motallebzadeh, 2016), and they might support students in producing meaningful output, yet this might not be as easy as it sounds in practice.

\section{Method}

This qualitative case study aims to explore the experience of intermediate learners of English in using podcasts to improve listening, speaking and pronunciation skills. A case study could be defined as "a research approach in which one or a few instances of a phenomenon are studied in depth" (Given, 2008, p. 68). It is carried out to develop a thorough understanding of a particular phenomenon (Creswell, 2002). The researcher wanted to investigate if podcasts could provide EFL learners with meaningful input to help them produce meaningful output. The study lasted an academic year and it aimed to answer the following research questions: (Q1) How does the use of podcasts affect the participants' attitudes towards extensive listening? (Q2) To what extent does listening to podcasts extensively help provide meaningful input? (Q3) What is the perceived value of listening to podcasts extensively in improving students' speaking skills? (Q4) What are the criteria that the students use to select podcasts for listening and how do they work with them?

\section{Participants}

The participants in this study were eight intermediate learners of English. Seven of them agreed to participate in the focus group interview. They were freshmen at an English-major department. They had no experience with extensive listening, and they previously studied mostly English grammar and vocabulary, while the study on productive skills was minimized at high school. They were not accustomed to listening to English except for English songs. This was apparent as the participants sometimes complained about the difficulties that they were having due to lack of previous experience with listening, not only during the project but also during the interviews. Moreover, such data matched the researcher's personal experience he gained at high schools, where he previously worked as a teacher and where he is currently doing teacher-training activities. Moreover, it is almost common knowledge that the washback effect of high-stakes examinations undermines the work in productive skills at high schools in Turkey.

\section{Procedure}

The participants were asked to find a short podcast and study it extensively out of the classroom every week and do several activities before they came to class. They were advised to listen to podcasts or read their transcripts before selecting one for the 
related week. In this sense, the selection process involved listening to parts of a podcast or skimming its transcript to decide if it was interesting for themselves and hopefully for their peers. Because the students were to do lots of listening work with the podcast after the selection, the way they selected it (through listening or reading) did not matter much. The benefit of such a practice was to encourage them not only to listen and read extensively but also find a topic that could be of interest to their audience (peers). As they found the podcast of the week, they were expected to listen to it, advisably several times, and work on the transcript to deal with new vocabulary. They were also asked to take down notes to be used in the discussion/presentation (Figure 1).

Figure 1. The Procedure te Participants Followed While Working with the Podcasts

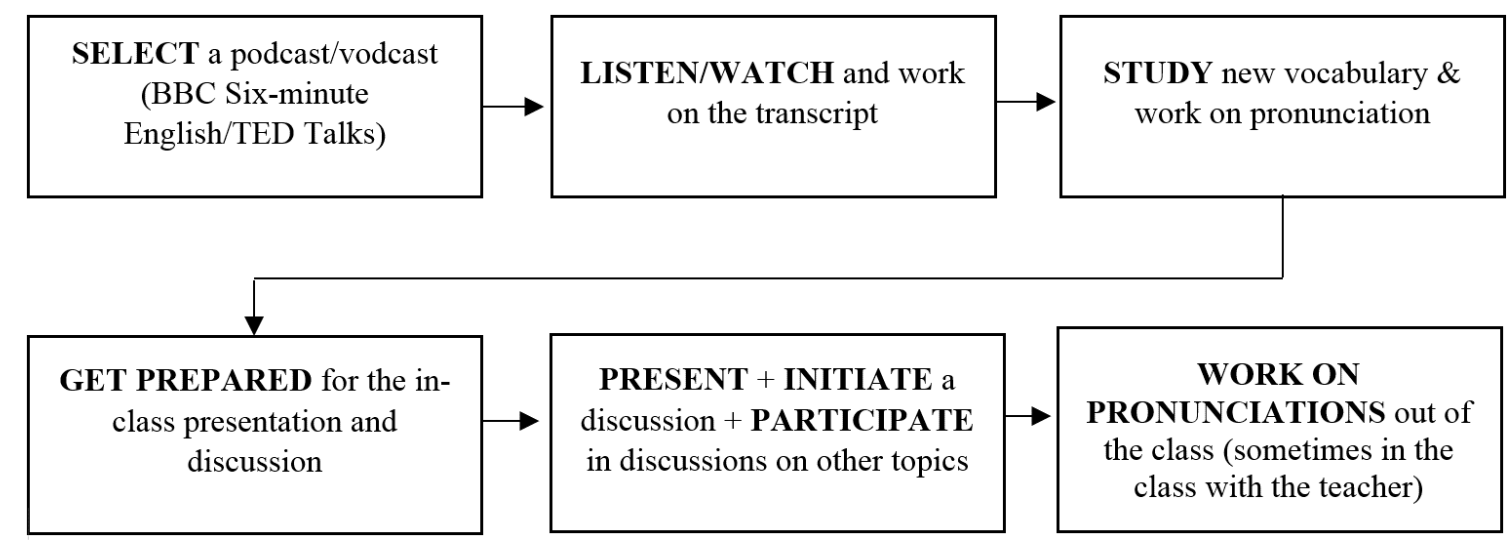

The participants in the present study mostly used Six Minute English and sometimes TED Talks. While the former includes conversations usually between native English speakers, videos in TED Talks include videos with speakers from all over the world. These two sources, in combination, helped the participants be exposed to a variety of accents that they could possibly hear in intercultural contexts. The podcasts that the participants listened to covered a wide variety of topics from science to personal development and from topics that promoted environmental awareness to answers to interesting questions, such as "How do pets navigate?" or "Why do we sigh?" (Six Minute English). Similar topics are found in TED Talks as well. Such a wide variety of topics enabled the participants to choose a topic of their own interest. The participants were also allowed to look for podcasts in other podcast sites on the Internet. The purpose was to encourage them to listen to what they are interested in to retain their motivation. The practice of selecting, studying and presenting, discussing and so forth was done every week throughout an academic year, allowing students to be exposed to authentic speech regularly.

\section{Data Collection and Analysis}

The researcher carried out a focus group interview at the end of the instructional period. In the focus group interview, the researcher asked the students to discuss their experience of doing extensive listening with podcasts and making in-class presentations and holding in-class discussions. The interview was carried out in the native language of the participants to help them express themselves better. Direct quotes presented in the discussion section were translated into English by the researcher himself and an experienced translator revised them to improve the quality of the translation. The focus 
group interview was audio-recorded, and the recordings were transcribed. The interview transcripts were analyzed using Nvivo v10. During the analysis, the researcher continuously kept a record of his thinking by means of annotations and memos. In NVivo, he created a code called "analytic codes," (a tool that was intended to organize the researcher's analytic thinking) in which there were some child nodes (sub-codes related with the category mentioned), such as potential quotes, live metaphors, if-then tactics, dilemmas in coding and so forth. These nodes helped the researcher keep track of the analysis. He initially asked questions to understand the data and kept a record of these questions as well. Taking the literature and the initial reading of the transcripts as a point of departure, the researcher tested some preliminary findings against interview transcripts. He did not use any initial list of codes (from the literature); all the codes emerged during the analysis. After open coding, the researcher went through the codes several times merging or separating them or removing some codes to ensure homogeneity within each code and heterogeneity across the codes. Finally, the selective coding phase, the researcher went on coding until no more coding seemed possible.

To ensure the credibility of the data, member checking was carried out. The researcher presented the interview transcripts to the respondents through email, requesting them to check the transcripts if anything was mistranscribed and if there was anything they wanted him to remove from the transcript. Moreover, the interviewees were given coded names to ensure anonymity, and the data were kept in a private computer in hidden files to ensure confidentiality. The only person who listened to the transcripts was the one who helped the researcher transcribe the data and the researcher made sure that he did not keep any copies of the transcripts.

\section{Results}

This section presents the results of the study. Globally considered, the participants saw value in listening to podcasts extensively, and they reported that listening to them provided meaningful input.

\section{A Change in the Participants' Attitude}

The interview respondents frequently contrasted the beginning and at the end of the project with respect to their perceived ability to speak and to understand spoken language and how they felt about the listening to podcasts outside the class. The participants' attitude towards the use of podcasts for extensive listening was not the same at the beginning and at the end of the project. First, the respondents reported that they had a positive attitude towards the use of podcasts for extensive listening, but they also noted that they didn't think so at initial stages of the project; their attitudes improved in time.

\section{Meaningfulness of the Input}

They participants reported that they mostly liked the subjects their peers selected. Moreover, the discussions were engaging, especially towards the end of the academic year. One interview respondent (IP01) reminded his friends and the researcher of a particular day on which they left the class an hour later than the usual time, and he attributed this extended class time to the engaging nature of that particular discussion. He also added that this particular session was the most engaging one, although such sessions were quite rare. Such high levels of engagement pointed to meaningful input 
because if the input had not been meaningful enough students would not have enjoyed what they discussed.

Another significant indication of meaningful input was that the participants considered podcasts as a way of improving their world knowledge. As improving one's world knowledge is a real-life purpose, listening to the podcasts became meaningful in time. In addition to this, the interaction among the students in the discussions was sometimes intended for a real-life purpose, leading to meaningful output. For example, one respondent selected a topic that is related to a phobia (dental phobia) that one of his peers suffered from. He explained: "For example, in one of the presentations, I tried to tease P05; that was so cool. I was curious about what his reaction would be. You know it was about the drill that dentists use" (IP01). The potential interaction between these two people with respect to this issue would be meaningful because IP01 wanted to tease his friend.

\section{Positive Impact of Listening to Podcasts on the Participants Speaking Skills}

As noted above, the participants considered the weekly task as something to be completed rather than something to be utilized to improve themselves. IP01, who seemed much more confident than the rest, described his desperate struggle as follows: "At times, my grammar knowledge falls short and I feel inadequate. I can't say anything, and while I keep silent, the topic gets changed." Despite his apparent selfconfidence, this participant seemed highly sensitive with respect to the reactions to the way he spoke and the topics he selected. Second, as the participants did not have much experience with (public) speaking previously, they felt shy while speaking in front of their peers although the class was a friendly environment with a small number of students. They felt highly stressed and embarrassed (four interview participants made 9 references to these feelings). The following quote depicts how stress and embarrassment confused and undermined the participants:

The moment you intend to say something, sixteen pairs of eyes instantly turn and look at you; they are curious about what you will say. Meanwhile, you get stressed and begin to consider how to express what you think... At that moment, you get confused and forget what you have to say; your grammar in different sentences gets jumbled together. You either have nothing to say or utter foolish or wrong sentences... (IP01).

Their account of how they felt during the discussions usually included such words as "embarrassment," "shy," "shyness," "stress," "stressful" "strain" and so forth. They usually felt uneasy during the time eight pair of eyes (including the researcher's) were carefully tracking them. One respondent, who was apparently fond of figurative language, used a live metaphor to describe their perspective of the audience with whom they interacted: "Just like lions carefully observing impalas. It is actually we who are impalas...those who speak..." (IP06).

The respondents also had difficulty in taking the floor. While they were trying to cope with the inability to remember content and appropriate words and grammatical structures to express it, they often recognized that they were unable to take the floor. As they reported, trying to find the best way of expressing something caused them to be late for expressing themselves as the direction of conversation changed too quickly for them to follow. Moreover, especially at initial stages of the process, they felt that they 
were unable to call on words that they wanted to use in their speech (two interview participants made three references to this). In short, they had difficulty in adapting themselves to the pace of conversation.

As most of them accepted, taking part in in-class discussions helped them express themselves better in front of a group. As the focus group interview revealed, a particularly significant change in their line of thought was that, at the end of the academic year, they no longer saw perfectionism as a goal to be attained. They came to realize that it was not a problem to produce less-than-perfect sentences. One respondent highlighted that he could express himself perfectly well although he produced sentences with grammatical problems or sentences without subjects or other essential elements. It seems that eliminating perfectionism worked a great deal because the respondents predominantly stated that they improved their fluency. In brief, they got around a significant bottleneck that delayed their progress in expressing themselves in English. This podcast project helped the participants improved their fluency. As noted earlier, the participants reported that were better at remembering the content and calling on words and they were able to express themselves better.

In addition to these, the participants had a chance to put into practice what they studied in the pronunciation component of the course. The participants reported that they also improved themselves with respect to the following points:

- presentation skills (e.g., planning, saluting people and introducing oneself at the beginning of the presentation, arousing interest, dealing with nervousness and so on) (IP01; IP02; IP04 and IP06) (The course involved listening, and speaking accompanied it to ensure skills integration. The participants presented their topic on a weekly basis and tried to involve the rest of the class by asking questions and seeking their opinions. Therefore, presentation skills were naturally involved as a component of academic speaking skills.)

- listening skills (e.g., recognizing weak forms, being able to catch the gist of the listening text, understanding informal language, summarizing longer listening passages (IP01)

- pronunciation (improving the pronunciation of commonly mispronounced words and developing awareness of stress and intonation (IP01)

- speaking fluently and remembering content from the listening text better (IP04)

The participants studied the podcasts in different ways, particularly with respect to how they used the transcript and the audio. Some listened to the audio once or several times first and then studied the transcript, while some others listened to the audio and looked at the transcript at the same time. The latter reported that they saw value in listening and reading simultaneously as it helped them improve their pronunciation. Table 1 presents data on how they used the transcripts. 
Table 1

Details about How the Respondents Used the Transcripts

\begin{tabular}{|c|c|c|}
\hline Respondent & How he/she used the transcript & Notes \\
\hline IP01 & $\begin{array}{l}\text { Listened to the audio twice first and } \\
\text { checked the transcript }\end{array}$ & $\begin{array}{l}\text { Sometimes gave up listening and checked } \\
\text { the transcript }\end{array}$ \\
\hline IP02 & No response & - \\
\hline IP03 & $\begin{array}{l}\text { Listened to the audio and read the text at } \\
\text { the same time (did shadow reading) }\end{array}$ & $\begin{array}{l}\text { Was able to remember the correct } \\
\text { pronunciation better in this way/realized } \\
\text { that he forgot the pronunciation when he } \\
\text { listened only }\end{array}$ \\
\hline IP04 & $\begin{array}{l}\text { Listened to the audio and read the text } \\
\text { simultaneously only once }\end{array}$ & $\begin{array}{l}\text { Found shadow reading boring, so listened } \\
\text { to the audio several times after the first } \\
\text { shadow reading }\end{array}$ \\
\hline IP05 & $\begin{array}{l}\text { Did shadow reading }+ \text { read the text without } \\
\text { the audio and listened to the audio without } \\
\text { the text }\end{array}$ & - \\
\hline IP06 & Read the text first and then listened to it & $\begin{array}{l}\text { Finds it inappropriate to read first, but he } \\
\text { did it to get familiar with the topic first }\end{array}$ \\
\hline IP07 & Listened to the audio and then read the text & $\begin{array}{l}\text { As she saw the value of listening to } \\
\text { podcasts, she wishes that she had listened } \\
\text { to the audio more than once. }\end{array}$ \\
\hline
\end{tabular}

Note. The researcher reports the data regarding how the respondent used the transcript (in response to the question "How did you use the transcripts?")

\section{Criteria for the Selection of the Podcasts}

The respondents used various criteria while selecting the podcasts. The most frequently used criterion was interest. Understandably, they tried to select interesting topics. Some of them took into account the length of the transcript as well. Some students at times preferred video podcasts (vodcasts) usually from TED Talks, finding them more comprehensible than audio files. One student mentioned selecting appropriate topics to be presented in the classroom. As they heard some positive reactions from their peers, they began to pay more attention to topic selection as they wanted to choose topics that were interest to a wider audience. In other words, they voiced their desire to choose topics that could be interesting for both girls and boys in this case. They probably spent more time and listened and read more as they wanted to find more interesting topics. Finally, the level of the listening texts was also considered as they tried to select topics that were appropriate for their level.

\section{Discussion}

One of the perceived benefits of this podcast project was that the participants improved themselves with respect to both listening and speaking skills. This key finding substantiates those from various studies (Alm, 2013; Ashraf, Noroozi \& Salami, 2011; Giordano, 2016; Li, 2010). During the discussions, the researcher took note of pronunciation problems and he focused on these at times. This might have been influential in the perceived improvement in the students' pronunciation. Another possibility could be the regular exposure to authentic speech through podcasts. 
Remarkably, the results also indicated that the participants improved their fluency and were better at remembering the contents during speaking. This in turn seemed to have a positive impact on their presentation skills. Perhaps, the most significant finding emerging from this study was that the consistent use of podcasts as a tool for extensive listening and in-class discussions as a follow up provided the participants with meaningful input, which sometimes helped them produce meaningful output. Finally, although it was not in the sense mentioned by some researchers (Al Fadda \& Al Qasim, 2013; Bradbury, 2016; Chan et al., 2011), the small group of learners seemed to function as a partially real audience (composed of peers) because the students wanted to choose the most interesting topics to grab the attention of their peers and impress them. In short, such perceived benefits of podcasts apparent in the present study seemed to justify Constantine's (2007) description that highlighted the value of podcasts.

As the interviews revealed, the participants initially did their weekly task, mainly because it was compulsory. Knowing that they will have their turn to bring their topic up for discussion because of the small number of students in the class, they rarely missed the task; more than $90 \%$ of the time they completed it. Such a context, as they stressed, came with social pressure, which made it difficult to give a negative response to the question "Have you done your assignment?" However, as time passed and they got used to working with podcasts and recognized their value, the respondents considered them not only informative but also fun to listen to. Therefore, a significant point of investigation for the researcher was to find out the reasons for change in the participants' attitude towards podcasts. To answer this question, the researcher examined several important nodes about the overall attitude they adopted towards this podcast project and perceived improvement in language skills, language areas, presentation skills and so forth.

To be able to better understand the results of this study, it is important to understand the context, in which the participants received instruction. As noted earlier, grammar and vocabulary were emphasized at the expense of listening and productive language skills at high school. This mostly had a negative impact on the students' participation levels (in the discussions) and their overall attitude towards this podcast project. The participants mentioned two major reasons for weaker participation in the in-class discussions. They felt that they were unable to call on words that they wanted to use in their speech, particularly at the beginning of the project. They also complained that they felt insufficient in expressing themselves and struggled hard to find the best way of saying something, so they were unable to keep pace with the others speakers (who sometimes read from notes rather than telling). "Reading" basically refers to the act of checking their transcripts to remember the content although they sometimes read sentences, which became less frequent in time. A wide range of topics they had access to and perceived improvement in their speaking skills perhaps played a leading role in the change for the positive in their attitudes.

Almost all of the participants $(n=6)$ used the transcripts of the podcasts while they were studying. This lent support to previous studies highlighting the positive impact of providing transcripts (Constantine, 2007; Hazell-Yildirim \& Hoffman, 2010; Hennig, 2017a, 2017b; Li, 2010; Lu, 2007; Yeh, 2013). However, a conspicuous result from the interview data about the use of transcripts was that the way the participants used the transcripts showed dramatic individual variation, suggesting that it may not be 
sensible to adopt a one-for-all approach when it comes to transcript use. Depending on their personal learning styles, learners may prefer to use the transcripts before or after they listen to the text, or they might prefer to listen to and read the text simultaneously. In this respect, this study indicated that letting students enjoy maximum freedom in selecting podcasts and studying them could provide more positive academic gains.

The findings of this study also indicated that persistence was one of the keys to success. As the participants in this study had a slender chance to express themselves in previous English classes, it was difficult for them to adopt the habit of listening for enjoyment. The researcher asked them to do their weekly tasks regularly and tried to establish a friendly environment in which they could express themselves freely (although it was sometimes not possible due to personal characteristics of students and the educational context in which they were brought up). However, the data from the interview indicated that this was possible at the end of the academic year to a great extent. Some students (e.g., IP07) even reported that they would listen to podcast during the summertime ahead. This is something significant because it is important for learners to take responsibility of their own learning. The findings of the present study indicate that extensive listening could be a regular part of classes with the help of consistent practice and patience.

\section{Conclusion}

This study reports the experiences of 8 EFL learners, using podcasts in a listening and pronunciation class. In this study, the researcher explored what it means to be a part of a lesson that is different from mainstream classes. This podcast project was helpful in improving the participants' listening and speaking skills. More importantly, the results indicated that listening to podcasts provided the learners with some meaningful input. This in turn made the experience more beneficial for the students, particularly towards the end of the academic year. This suggests that out-of-class listening using podcasts could function as food for thought for in-class discussions in which students need something to talk about.

\section{Limitations and Further Research}

One of the limitations of this study is that the researcher did not triangulate the data by using observations, surveys and so forth. Moreover, it is not certain if this podcast project could be implemented in a crowded class, because not every student could have the chance to express him/herself in a limited time in such classes. A possible solution for this could be to ask students to produce speech using technological devices and share their speech online. Producing podcasts and sharing them online were beyond the scope of the present study; prospective work could focus on the use of podcast to increase the amount of student talking time outside the class. 


\section{References}

Abdous, M. H., Camarena, M. M., \& Facer, B. R. (2009). MALL technology: Use of academic podcasting in the foreign language classroom. ReCALL, 21(1), 76-95. https://doi.org/10.1017/S0958344009000020

Ahn, J., Inboriboon, P. C., \& Bond, M. C. (2016). Podcasts: Accessing, choosing, creating, and disseminating content. Journal of Graduate Medical Education, 8(3), 435-436. https://doi.org/10.4300/JGME-D-16-00205.1

Al Fadda, H., \& Al Qasim, N. (2013). From CALL to MALL: The effectiveness of podcast on EFL higher education students' listening comprehension. English Language Teaching, 6(9), 30-41. https://doi.org/10.5539/elt.v6n9p30

Alm, A. (2013). Extensive listening 2.0 with foreign language podcasts. Innovation in Language Learning and Teaching, 7(3), 266-280. https://doi.org/10.1080/17501229.2013.836207

Alshaikhi, D., \& Madini, A. A. (2016). Attitude toward enhancing extensive listening through podcasts supplementary pack. English Language Teaching, 9(7), 32-47. https://doi.org/10.5539/elt.v9n7p32

Ashraf, H., Noroozi, S., \& Salami, M. (2011). E-listening: The promotion of EFL listening skill via educational podcasts. In Proceedings of the 6th International Conference on e Learning (ICEL) (pp. 10-17). Oxfordshire, UK: Academic Conferences and Publishing International.

Bittenbender, K., \& Von Koss, N. (2008). Using podcasting in the foreign language classroom. INTO Faculty and Staff Publications. Retrieved from http://scholarcommons.usf.edu/info_facpub/11

Bradbury, J. (2016). Podcasts expand classroom walls. Education Digest, 81(8), 46-48.

Carvalho, A., Aguiar, C., \& Maciel, R. (2009). A taxonomy of podcasts and its application to higher education. Paper presented at the ALT-C 2009, Manchester, UK. Retrieved from http://repository.alt.ac.uk/638/1/ALTC_09_proceedings_090806_web_0161.pdf

Chan, W. M., Chi, S. W., Chin, K. N., \& Lin, C. Y. (2011). Students' perceptions of and attitudes towards podcast-based learning: A comparison of two language podcast projects. Electronic Journal of Foreign Language Teaching, 8(1), 312-335.

Clark, W., Logan, K., Luckin, R., Mee, A., \& Oliver, M. (2009). Beyond Web 2.0: Mapping the technology landscapes of young learners. Journal of Computer Assisted Learning, 25(1), 56-69. https://doi.org/10.1111/j.1365-2729.2008.00305.x

Constantine, P. (2007). Podcasts: another source for listening input. The Internet TESL Journal, 13(1). Retrieved from http://iteslj.org/Techniques/ConstantinePodcastListening.html

Creswell, J. W. (2002). Educational research : Planning, conducting, and evaluating quantitative and qualitative research. Upper Saddle River, N.J.: Merrill.

Ducate, L., \& Lomicka, L. (2009). Podcasting: An effective tool for honing language students' pronunciation? Language Learning \& Technology, 13(3), 66-86.

Facer, B., Abdous, M. and Camarena, M. (2008) The impact of academic podcasting on students: Learning outcomes and study habits. In: de Cassia Veiga Marriott, R. \& 
Lupion Torres, P. (Eds.) Handbook of research on e-learning methodologies for language acquisition (pp. 339-351). Birmingham, UK: Cypertech Publishing.

Farangi, M. R., Nejadghanbar, H., Askary, F., \& Ghorbani, A. (2015). The effects of podcasting on EFL upper-intermediate learners' speaking skills. CALL-EJ, 16(2). Retrieved from http://callej.org/journal/162/Faranji_Nejadghanbar_Askary_Ghorbani2015.pdf

Fox, A. (2008). Using Podcasts in the EFL Classroom. TESL-EJ, 11(4). Retrieved from http://www.tesl-ej.org/ej44/a4.pdf

Giordano, M. J. (2017). Extensive listening using student-generated podcasts. In P. Clements, A. Krause, \& H. Brown (Eds.), Transformation in language education (pp. 429-435). Tokyo: JALT.

Given, L. M. (Ed.) (2008). The Sage encyclopedia of qualitative research methods. Thousand Oaks, CA: Sage Publications. https://doi.org/10.4135/9781412963909

Hasan, M., \& Hoon, T. B. (2013). Podcast applications in language learning: A review of recent studies. English Language Teaching, 6(2), 128-135.

Hazell-Yildirim, A., \& Hoffman, E. (2010). The power of podcats: A tool to improve listening skills and empower learners. In N. Ashcraft \& A. Tran (Eds.), Teaching listening: Voices from the field (pp. 115-132). Annapolis Junction, MD: TESOL Press.

Heilesen, S. B. (2010). What is the academic efficacy of podcasting? Computers \& Education, 55, 1063-1068. https://doi.org/10.1016/j.compedu.2010.05.002

Hennig, N. (2017a). Podcasts in context. Library Technology Reports, 53(2), 30-38.

Hennig, N. (2017b). Recommended tools for podcast listening. Library Technology Reports, 53(2), 10-15.

Jain, S., \& Hashmi, F. (2013). Advantages of podcast in English language classroom. Journal of Indian Research, 1(2), 158-163.

Jones, C., Ramanau, R., Cross, S., \& Healing, G. (2010). Net generation or digital natives: Is there a distinct new generation entering university? Computers \& Education, 54(3), 722-732. https://doi.org/10.1016/j.compedu.2009.09.022

Krashen, S. D. (1982). Principles and practice in second language acquisition. Oxford: Pergamon.

Krashen, S. D. (1985). The input hypothesis: Issues and implications. New York: Longman.

Krashen, S. D. (1989). Language acquisition and language education: Extensions and applications. Hertfordshire: Prentice Hall.

Li, H. C. (2010). Using podcasts for learning English: perceptions of Hong Kong Secondary 6 ESL students. Début: the undergraduate journal of languages, linguistics and area studies, 1(2), 78-90.

Lu, J. A. (2007). Podcasting: A fresh solution for old problems. Wireless Ready eProceedings: Podcasting Education and Mobile Assisted Language Learning, 8395.

Mayora, C. A. (2017). Extensive listening in a Colombian university: Process, product, and perceptions. HOW, 24(1), 101-121. https://doi.org/10.19183/how.24.1.311 
McDonough, J., Shaw, C., \& Masuhara, H. (2013). Materials and methods in ELT : a teacher's guide (Third edition. ed.). Chichester, West Sussex England; Malden, MA: Wiley-Blackwell.

McGarr, O. (2009). A review of podcasting in higher education: Its influence on the traditional lecture. Australasian Journal of Educational Technology, 25(3), 309321. https://doi.org/10.14742/ajet.1136

Naseri, S., \& Motallebzadeh, K. (2016). Podcasts: A Factor to Improve Iranian EFL Learner' Self-Regulation Ability and Use of Technology. Journal of Educational Technology \& Society, 19(2), 328-339.

Nesi, C. J. (2016). The power of podcasts. Education Digest, 81(7), 36-38.

O’Bannon, B. W., Lubke, J. K., Beard, J. L., \& Britt, V. G. (2011). Using podcasts to replace lecture: Effects on student achievement. Computers \& Education, 57, 1885-1892. https://doi.org/10.1016/j.compedu.2011.04.001

Rahimi, M., \& Katal, M. (2012). The role of metacognitive listening strategies awareness and podcast-use readiness in using podcasting for learning English as a foreign language. Computers in Human Behavior, 28(4), 1153-1161. https://doi.org/10.1016/j.chb.2012.01.025

Selwyn, N. (2009). The digital native - myth and reality. Aslib Proceedings: New Information Perspectives, 61(4), 364-379. https://doi.org/10.1108/00012530910973776

Şendağ, S., Gedik, N., Caner, M., \& Toker, S. (2017). Mobil-yoğun-podcast dinlemenin İngilizce öğretmen adaylarinin dinleme, konuşma ve eleştirel düşünme becerilerine etkisi. Educational Technology Theory and Practice, 7(2), 94-112.

Stanley, G. (2006). Podcasting: Audio on the Internet comes of age. TESL-EJ, 9(4). Retrieved from http://www.tesl-ej.org/ej36/int.pdf

Sze, P. (2006). Developing students' listening and speaking skills through ELT podcasts. Education Journal-Hong Kong-Chinese University Of Hong Kong, 34(2), $115-134$.

Thorne, S., \& Payne, J. (2005). Evolutionary trajectories, internet-mediated expression, and language education. CALICO, 22(3), 371-397. https://doi.org/10.1558/cj.v22i3.371-397

Tomlinson, B. (2011b): Introduction: principles and procedures of materials development. In B. Tomlinson (Ed.), Materials development in language teaching (2nd ed.), (pp. 1-34). Cambridge: Cambridge University Press

Walls, S. M., Kucsera, J. V., Walker, J. D., Acee, T. W., McVaugh, N. K., \& Robinson, D. H. (2010). Podcasting in education: Are students as ready and eager as we think they are? Computers \& Education, 54, 371-378. https://doi.org/10.1016/j.compedu.2009.08.018

Yeh, C. C. (2013). An investigation of a podcast learning project for extensive listening. Language Education in Asia, 4(2), 135-149. https://doi.org/10.5746/LEiA/13/V4/I2/A04/Yeh 


\section{Appendix}

\section{Focus Group Interview Questions}

1. What was the impact of this podcast project on your listening skills?

2. What was the impact of this podcast project on your speaking skills?

3. What was the impact of this podcast project on your pronunciation?

4. How did you use the transcript?

Probe: Advantages/disadvantages?

5. How did the in-class discussions/presentations affect your presentation skills? Can you explain it using examples?

6. How did you reflect on the podcasts that you listened to?

7. How do you evaluate your participation in the discussions/presentations?

8. How did this project affect your self-confidence in speaking?

9. How did you select the podcasts? What were your criteria for selection?

10. How did you feel during the process (from selecting and listening to the podcasts to discussing/presenting it in the class)?

11. How did you feel when you were not able to do your weekly assignment?

12. How did regular (weekly) practice affect you with respect to access to materials, feelings, stress levels and so forth?

13. What would you recommend the researcher to carry out this project better?

This is an Open Access article distributed under the terms of the Creative CommonsAttributionNonCommercial-ShareAlike 4.0 International (CC BY-NC-SA 4.0). For further information, you can refer to https://creativecommons.org/licenses/by-nc-sa/4.0/ 